\title{
PERAN KEPALA KELUARGA DENGAN PENERAPAN PROTOKOL KESEHATAN DI KABUPATEN ACEH UTARA
}

\section{THE ROLE OF FAMILY HEAD ON THE IMPLEMENTATION OF HEALTH PROTOCOL IN ACEH UTARA REGENCY}

\author{
Sabahul Badri, Eridha Putra \\ Prodi Sarjana Keperawatan, Universitas Bina Bangsa Getsempena, Jln. Tanggul Krueng Lamnyong No.34, Rukoh, \\ Kec. Syiah Kuala, Kota Banda Aceh. Indonesia \\ Correspondence Email : sabahulbadriget@gmail.com
}

\begin{abstract}
ABSTRAK
Kepala keluarga memiliki peran penting sebagai pendidikdalam upaya mencegah penularan virus Covid-19, keluarga menjadi tempat yang rawan bagi penularan virus Corona.Kondisi seperti ini tentunya berbahaya bagi anggota keluarga, karenanya diperlukan antisipasi atau pencegahan dari terpaparnya Covid-19 didalam keluarga, salah satunya melalui peran kepala keluarga.Penelitian ini bertujuan untuk mengetahui peran kepala keluarga dengan penerapan protokol kesehatan di Desa Rawa Kecamatan Tanah Luas Kabupaten Aceh Utara.Penelitian kuantitatif ini dengan desain correlation analitik dengan teknik pengambilan sampel menggunakan random samplingpada53 kepala keluarga. Analisis uji statistic menggunakan Uji Chi-Square. Hasil penelitian menunjukkanbahwa sebanyak 39,6\%peran kepala keluarga berada pada kategori kurang dansebanyak 69,8\%kepala keluarga tidak menerapkan protokol kesehatan.Ada hubungan yang signifikan hubungan peran kepala keluarga terhadap penerapan protokol kesehatan di Desa Rawa Kecamatan Tanah Luas Kabupaten Aceh Utara dengan nilai ( $p$ value $=0,000 ; \alpha=0,05$ ). Diharapkan untuk optimalisasi sosialisasi dan edukasi tentang protokol Covid-19 dan peran kepala keluarga dalam masyarakat dengan melibatkan tokoh adat, alim ulama dan tokoh masyarakat, mengoptimalkan gerakan sosialisasi dan penyebarluasan informasi penanganan Covid-19.
\end{abstract}

Kata kunci:kepala keluarga; protokol; covid-19

\begin{abstract}
The head of the family has an important role as an educator in an effort to prevent the transmission of the Covid-19 virus; the family becomes a vulnerable place for the transmission of the Corona virus. One of which is through the role of the head of the family. This study was aimed to determine the role of the head of the family with the implementation of health protocols in Rawa Village, Tanah Luas District, North Aceh Regency. This quantitative study was an analytical correlation design with a sampling technique using random sampling of 53 families. Statistical test analysis used Chi-Square Test. The results showed that as many as $39.6 \%$ of the role of the head of the family were in the fewer categories and as many as $69.8 \%$ of the head of the family did not apply the health protocol. There is a significant relationship between the role of the head of the family on the implementation of health protocols in Rawa Village, Tanah Luas District, North Aceh Regency with a value ( $p$ value $=0.000 ;=0.05$ ). It is expected to optimize socialization and education about the Covid-19 protocol and the role of family heads in society by involving traditional leaders, religious scholars and community leaders, optimizing the socialization movement and disseminating information on handling Covid-19.
\end{abstract}

Keywords: family head; protocol; covid-19

Jurnal SMART Keperawatan is licensed under a Creative Commons Attribution-ShareAlike 4.0 International License. 


\section{PENDAHULUAN}

Coronavirus merupakan kumpulan virus yang bisa menginfeksi sistem pernapasan.Pada banyak kasus, virus ini hanya menyebabkan infeksi pernapasan ringan, seperti flu.Namun, virus ini juga bisa menyebabkan infeksi pernapasan berat, seperti infeksi paru-paru (pneumonia)(Perhimpunan Dokter Paru Indonesia (PDPI), 2020).

Eropa dan Amerika Utara telah menjadi pusat pandemi covid-19, dengan kasus dan kematian sudah melampaui China. Amerika Serikat menduduki peringkat pertama dengan kasus covid-19 terbanyak dengan penambahan kasus baru sebanyak 19.332 kasus pada tanggal 30 Maret 2020 disusul oleh Spanyol dengan 6.549 kasus baru. Italia memiliki tingkat mortalitas paling tinggi di dunia, yaitu 11,3\%(Kemenkes RI, 2020).

Covid-19 pertama dilaporkan di Indonesia pada tanggal 2 Maret 2020 sejumlah dua kasus.Data 31 Maret 2020 menunjukkan kasus yang terkonfirmasi berjumlah 1.528 kasus dan 136 kasus kematian.Sedangkan pada 27 Juli 2020 sudah naik menjadi 98.778 orang dengan jumlah kematian 4.781 orang. Tingkat kematian (case fatality rate) akibat covid-19 adalah sekitar 4,8\%. Tingkat mortalitas covid-19 di Indonesia sebesar 8,9\%, angka ini merupakan yang tertinggi di Asia Tenggara. Per 30 Maret 2020, terdapat 693.224 kasus dan 33.106 kematian di seluruh dunia (Kemenkes RI, 2020).

Provinsi Aceh pertama sekali mendapatkan laporan pasien pertama yang mengalami Covid-19 pada tanggal 23 maret 2020.Data tentang kasus covid-19 tercatat secara signifikan di Aceh pada tanggal 01 April 2020, Jumlah Orang Dalam Pemantauan (ODP) tercatat sebanyak 893 kasus.Ada penambahan ODP sebanyak 96 kasus dibandingkan catatan kemarin, yang masih 797 kasus.Sampai per 16 Mei 2021.Jumlah kasus Covid-19 di Aceh secara akumulatif telah mencapai 12.249 kasus/orang.Para penyintas, yang sembuh dari Covid-19 sebanyak 10.309 orang. Pasien masih dirawat 1.446 orang, dan penderita yang meninggal dunia telah mencapai 494 orang (Info Covid-19. 2021).
Kabupaten Aceh Utara merupakan salah satu kabupaten di provinsi aceh yang mengalami peningkatan kasus terkonfirmasi COVID-19. Bupati kabupaten aceh utara mengeluarkan aturan Nomor 30 Tahun 2020 tentang Penerapan Disiplin Dan Penegakan Hukum Protokol Kesehatan Sebagai Upaya Pencegahan Dan Pengendalian Corona Virus Disease 2019 Di Kabupaten Aceh Utara.Data pasien Covid-19 di aceh utara terkonfirmasi secara komulatif dari tahun 2020 sampai dengan 2021 berjumlah 1053 kasus, pasien meninggal berjumlah 103 orang, suspek berjumlah 399 orang, dan pasien yang sembuh berjumlah 949 orang(Info Covid19. 2021).

Penularan virus corona terjadi secara droplet atau melalui percikan saat orang batuk atau berbicara, hal inilah yang menyebabkan virus ini mudah sekali menular ke orang lain (Wu et al., 2020). Sehubungan dengan tanda dan gejala yang tidak spesifik tersebut maka fokus untuk menekan jumlah kasus Covid-19 adalah mencegah penularan dengan merapkan protokol pencegahan penularan Covid19.Tanggung jawab pencegahan penularan adalah tanggung jawab bersama pemerintah dan masyarakat (Menteri Desa RI, 2020).

Hasil penelitian yang dilakukan Hodijah dan Wicaksana (2020) menunjukkan pemahaman dalam penerapan protokol kesehatan bagi masyarakat, yaitu berdasarkan rentang skor yang telah ditetapkan maka didapatkan 47\% sangat baik, 13 baik, 7\% sedang/ cukup, $7 \%$ kurang, $3 \%$ sangat kurang, dan 23\% tidak peduli. Secara keseluruhan tingkat pemahaman berdasarkan pengetahun adalah $64 \%$ dan berdasarkan sikap atau perilaku adalah 69\%.Dengan demikian pemahaman masyarakat terhadap protokol kesehatan Covid-19 tergolong sedang atau cukup paham. Namun mengingat wabah ini memiliki tingkat penularan yang sangat tinggi, maka keberadaan kelompok masyarakat yang kurang paham, sangat kurang paham, dan tidak peduli terhadap protokol kesehatan sangat berpotensi dalam penyebaran dan penularan wabah covid-19(Hodijah \& Wicaksana, 2020). 
Keluarga merupakan bagian terkecil dari masyarakat, didalam keluarga terdiri dari kepala keluarga dan beberapa orang lainnya yang tinggal dalam satu atap / satu rumah yang antara satu orang dan orang lainnya saling membutuhkan dan saling ketergantungan.Peranan kepala keluarga pada masa pandemic covid-19 ini merupakan salah satu kunci pencegahan Covid-19.Karena kepala keluarga memiliki peranan sebagai pendidik dan mengatur aktifitas rumah tangga. Selain itu kepala keluarga juga memiliki peran yang dijalankan terkait merawat anggota keluarga jika ada yang sakit (Friedman, 2015).

Hasil penelitian yang dilakukan Asmayanti et al., (2021) menjelaskan terdapat beberapa kendala yang dialami para orang tua yaitu mendisplinkan anggota keluarga dalam menjalani protokol kesehatan dan penambahan biaya untuk memperoleh alat kebersihan pribadi selama masa pandemi covid-19, adapun upaya yang dapat dilakukan dalam mengatasi problematika tersebut adalah orang tua sebagai pembimbing, pendidik, penjaga, pengembang dan pengawas. Secara spesifik menunjukkan bahwa peran orang tua dalam mencegah covid-19 adalah dengan menjaga dan memastikan seluruh anggota keluarga untuk menerapkan pola hidup bersih dan sehat di masa pandemic covid-19(Asmayanti et al., 2021).

Orang tua selaku Kepala keluarga harus bisa membiasakan keluarganya untuk melakukan penerapan protokol kesehatan seperti kampanye 3M, yaitu; pertama memakai masker dengan benar, demi melindungi anggota keluarga yang memiliki risiko tertular tinggi.Kedua ketika ada keluarga terpapar.Ketiga saat beraktifitas di luar rumah dan Keempat tidak memberikan stigma negatif kepada pasien COVID(Kemenkes, 2020)

Selain itu kepala keluarga juga harus memahami Protokol masuk rumah bagi siapapun yang datang berkunjung kerumah, antara lain yaitu; pada saat sampai rumah jangan sentuh apapun, buka sepatu sebelum masuk rumah, buka pakaian dan segera masukan kedalam keranjang cucian, segera mandi, kaluar gak bisa mandi, pastikan cuci semua area kulit yang terkena paparan udara luar, bersihkan handphone atau kacamata dengan desinfektan, bersihkan permukaan atau benda yang dibawa dari luar(Kemenkes RI, 2020).

Berdasarkan hasil survei awal didapatkan hasil yang mana dari 10 kepala keluarga yang diwawancarai, hanya 3 orang kepala keluarga yang memahami tentang protokol kesehatan.Selain itu kepala keluarga juga menjelaskan tidak pernah menjalankan protokol kesehatan sesuai yang ajurkan oleh pemerintah.Berdasarkan latar belakang diatas maka peneliti tertarik untuk melakukan penelitian tentang peran kepala keluarga dengan penerapan protokol kesehatan di desa Rawa Kecamatan Tanah Luas Kabupaten Aceh Utara.

\section{METODE}

Metode penelitian ini yaitu kuantitatif dengan desain correlation analitik dengan pendekatan cross sectional. Subjek penelitian ini yaitu kepala keluarga.Penelitian dilakukan di Desa Rawa pada bulan Juni s/d gustus 2021.

Populasi sebanyak 111 orang (kepala keluarga) dan untuk menentukan besarnya sampel penelitian menggunakan rumus (Notoatmodjo, 2018), dengan mengambil resiko salah dalam mengambil keputusan sebanyak $0,1 \%$ maka didapatkan sampel 53 orang responden.

Pengambilan sampel menggunakan teknik random samplingdengan kriteria inklusi sebagai berikut:Kepala keluarga berdomisili di Desa Rawa Kecamatan Tanah Luas dan bersedia menjadi responden, Kepala keluarga dapat membaca dan menulis, Kepala Keluarga (ayah) bila dalam keluarga tersebuat terdiri dari ayah, ibu, dan anak atau Kepala keluarga (ibu) bila dalam keluarga tersebut statusnya janda, ayah sulit ditemui karena bekerja di luar desa atau ayah tidak bisa berinteraksi (sakit).

Penelitian ini dilakukan dengancara mengunjungiresponden dari rumah kerumah. Sebelum membagikan kuisioner, peneliti terlebih dahulu menjelaskan tentang tujuan penelitian dilanjutkan dengan mengisi lembar 
persetujuan responden, sebagai bukti sukarela menjadi responden.

Instrumen dalam penelitian ini menggunakan kuesioner yang mengukur tentang peran kepala keluarga dan penerapan protokol kesehatan. Adapun bentuk kedua kuesioner tersebut sebagai berikut: peran kepala keluarga menggunakan kuesioner sebanyak 10 pernyataan tentang peran kepala keluarga menggunakan skala likert dengan 4 pilihan jawaban. Pada pernyataan positif, jika responden menjawab "sangat setuju" diberi skor 4, "setuju" diberi skor 3, "tidak setuju" diberi skor 2 dan "sangat tidak setuju" diberi skor 1. Dan penerapan Protokol Kesehatan sebanyak 7 pernyataan menggunakan skala likert dengan 4 pilihan jawaban. Pada pernyataan positif, jika responden menjawab "sangat sering" diberi skor 4, "cukup sering" diberi skor 3, "jarang/kadang-kadang" diberi skor 2 dan "tidak pernah" diberi skor 1.

Hasil uji validitas terhadap kuesioner peran kepala keluarga diperoleh nilai 0,5690,867 (> r tabel $=0,553$ ) artinya alat ukur valid. Sedangkan untuk penerapan protokol kesehatan tidak diuji validitas karena diadopsi dari Kuesioner Survei Perilaku Masyarakat di Masa Pandemi (Badan Pusat Statistik, 2020). Adapun uji statistic yang dingunakan dalam penelitian ini adalah Uji Chi-Square (uji korelasi).

Peneltian ini telah dinyatakan lulus dan layak untuk melaksanankan penelitian oleh Lembaga Penelitian dan Pengabdian kepada Masyarakat (LPPM) Universitas Bina Bangsa Getsempena, berdasarkan Kontrak penelitian dengan No. 173/E4.1/AK.04.PT/2021.

\section{HASIL}

\section{Karakterisitk Responden}

Tabel 1 menjelaskan bahwa jenis kelamin respondensebanyak 67,9\%. Sebanyak 47,2\% responden berumur pada rentang 20 s/d 35 tahun. Mayoritas responden memiliki latar pendidikan tingkat sekolah menengah keatas (SMA) sebanyak 28,3\%. Sebanyak $26,4 \%$ responden memiliki pekerjaan sebagai wiraswasta. Tabel 1 ditunjukan dalam table berikut :
Tabel 1Distribusi berdasarkan Karakteristik Responden di Desa Rawa Kecamatan Tanah Luas Kabupaten Aceh Utara ( $n=53)$

\begin{tabular}{clcc}
\hline No & \multicolumn{1}{c}{ Karakteristik } & $f$ & $\%$ \\
\hline 1 & Jenis Kelamin & & \\
& a. Laki-laki & 36 & 67,9 \\
& b. Perempuan & 17 & 32,1 \\
\hline 2 & Umur & & \\
& a. 20-35 Tahun & 25 & 47,2 \\
& b. 36-45 Tahun & 12 & 22,6 \\
& c. 46-55 Tahun & 9 & 17,0 \\
& d. 56-65 Tahun & 5 & 9,4 \\
& e. >65 Tahun & 2 & 3,8 \\
\hline 3 & Pendidikan & & \\
& a. SD & 7 & 13,2 \\
& b. SMP & 14 & 26,4 \\
& c. SMA & 15 & 28,3 \\
& d. D3 & 7 & 13,2 \\
& e. S1 & 10 & 18,9 \\
\hline 4 & Pekerjaan & & \\
& a. Wiraswasta & 14 & 26,4 \\
& b. Petani & 13 & 24,5 \\
& c. PNS & 4 & 7,5 \\
& d. Tenaga Kesehatan & 4 & 7,5 \\
& e. Pengawai Swasta & 9 & 17,0 \\
& f. Lain-lain & 93 & 17,0 \\
\hline
\end{tabular}

\section{Peran Kepala Keluarga}

Tabel 2 menunjukkan bahwa sebanyak 39,6\% peran kepala keluarga pada kategori kurang dalam penerapan protokol kesehatan. 37,7\% peran kepala keluarga pada kategori cukup dalam penerapan protokol kesehatan dan sebanyak 22,6\% peran kepala keluarga pada kateori baik dalam penerapan protokol kesehatan.

Tabel 2Distrubusi frekuensi dan persentase berdasarkan Peran Kepala Keluarga Di Desa Rawa Kecamatan Tanah Luas Kabupaten Aceh Utara (n: 53)

\begin{tabular}{clcc}
\hline No & $\begin{array}{c}\text { Peran Kepala } \\
\text { Keluarga }\end{array}$ & $F$ & $\%$ \\
\hline 1 & Baik & 12 & 22,6 \\
2 & Cukup & 20 & 37,7 \\
3 & Kurang & 21 & 39,6 \\
\hline & Jumlah & 53 & 100 \\
\hline
\end{tabular}




\section{Penerapan Protokol Kesehatan}

Berdasarkan tabel 3. Penelitian ini menemukan bahwa sebanyak $69,8 \%$ kepala keluarga tidak menerapkan protokol kesehatan dan sebanyak $30,2 \%$ kepala keluarga menerapkan protokol kesehatan

Tabel 3Distrubusi frekuensi dan persentase berdasarkan Penerapan Protokol Kesehatan Di Desa Rawa Kecamatan Tanah Luas Kabupaten Aceh Utara ( $n=: 53)$

\begin{tabular}{cccc}
\hline No & $\begin{array}{c}\text { Penerapan Protokol } \\
\text { Kesehatan }\end{array}$ & $f$ & $\%$ \\
\hline 1 & Diterapkan & 16 & 30,2 \\
2 & Tidak Diterapkan & 37 & 69.8 \\
\hline & Jumlah & 53 & 100 \\
\hline
\end{tabular}

\section{Peran Kepala Keluarga Terhadap Penerapan Protokol Kesehatan}

Berdasarkan tabel 4.Penelitian ini menunjukkan bahwa sebanyak $39,6 \%$ peran kepala keluarga pada katagori kurang tidak menerapkan protokol kesehatan, sebanyak $22,6 \%$ peran kepala keluarga pada katagori cukup tidak tidak menerapkan protokol kesehatan, sedangkan sebanyak 12\% peran kepala keluarga pada katagori baik tidak menerapkan protokol kesehatan.

Hasil uji statistik Chi Square mengungkapkan bahwa ada pengaruh peran kepala keluarga terhadap penerapan protokol kesehatan di desa rawa kecamatan tanah luas kabupaten aceh utara ( $p$ value $=0,000 ; \alpha=$ $0,05)$. Hasil penelitian ini menunjukkan bahwa pentingnya pemahaman dan peran kepala keluarga dalam upaya pencegahan Covid 19 ditingkat keluarga.

Tabel 4 Peran Kepala Keluarga Terhadap Penerapan Protokol Kesehatan Di Desa Rawa Kecamatan Tanah Luas Kabupaten Aceh Utara $(n=53)$

\begin{tabular}{|c|c|c|c|c|c|c|c|}
\hline \multirow{3}{*}{$\begin{array}{l}\text { Peran } \\
\text { Kepala } \\
\text { Keluar- } \\
\text { ga }\end{array}$} & \multicolumn{4}{|c|}{$\begin{array}{c}\text { Penerapan Protokol } \\
\text { Kesehatan }\end{array}$} & \multirow{3}{*}{$\mathrm{n}$} & \multirow{3}{*}{$\%$} & \multirow{3}{*}{$\begin{array}{c}P \\
\text { Valu } \\
e\end{array}$} \\
\hline & \multicolumn{2}{|c|}{ Diterapkan } & \multicolumn{2}{|c|}{$\begin{array}{c}\text { Tidak } \\
\text { Diterapkan }\end{array}$} & & & \\
\hline & $f$ & $\%$ & $F$ & $\%$ & & & \\
\hline Baik & 8 & 15,1 & 4 & 7,5 & 12 & 22,6 & \\
\hline Cukup & 8 & 15,1 & 12 & 22,6 & 20 & 37,7 & 0,00 \\
\hline Kurang & 0 & 0,0 & 21 & 39,6 & 21 & 39,6 & \\
\hline Total & 16 & 30,2 & 37 & 69,0 & 53 & 100 & \\
\hline
\end{tabular}

\section{PEMBAHASAN}

Peran kepala keluarga terhadap penerapan protokol kesehatan di desa rawa, yaitu sebanyak 39,6\% peran kepala keluarga pada katagori kurang tidak menerapkan protokol kesehatan, mayoritas responden mengaku pernah mendapatkan edukasi tentang Covid19. Namun responden belum mendapatkan pemahaman tentang peranan kepala keluarga terhadap kesehatan dan motivasi untuk patuh terhadap penerapan protokol kesehatan.

Hasil penelitian yang dilakukan Hodijah dan Wicaksana (2020) menunjukkan pemahaman dalam penerapan protokol kesehatan bagi masyarakat, yaitu berdasarkan rentang skor yang telah ditetapkan maka didapatkan $47 \%$ sangat baik, 13 baik, 7\% sedang/ cukup, 7\% kurang, 3\% sangat kurang, dan 23\% tidak peduli. Secara keseluruhan tingkat pemahaman berdasarkan pengetahun adalah $64 \%$ dan berdasarkan sikap atau perilaku adalah 69\%.Dengan demikian pemahaman masyarakat terhadap protokol kesehatan Covid-19 tergolong sedang atau cukup paham. Namun mengingat wabah ini memiliki tingkat penularan yang sangat tinggi, maka keberadaan kelompok masyarakat yang kurang paham, sangat kurang paham, dan tidak peduli terhadap protokol kesehatan sangat berpotensi dalam penyebaran dan penularan wabah covid-19 (Hodijah \& Wicaksana, 2020).

Berdasarkan hasil penelitian ini menunjukkan sebanyak 69,8\%kepala keluarga tidak menerapkan protokol kesehatan, hal ini disebabkan oleh persepsi masyarakat yang menganggap penerapan protokol kesehatan tidak begitu penting. Selain itu pengadaan fasilitas yang mendukung untuk penerapan protokol kesehatan, seperti menyediakan tempat cuci tangan, sabun dan ketersedian masker yang harga mulai tinggi pada masa pandemic Covid 19.

Penerapan protokol kesehatan dalam bentuk menjaga jarak dan social distancing didalam masyarakat tidak diterapkan.Dimana masyarakat banyak menghabiskan waktu dengan berkumpul diwarung kopi, dan mengikuti kegiatan-kegiatan di desa tanpa 
adanya penerapan protokol kesehatan.Peneliti juga mengobservasi lingkungan rumah warga tidak ada tempat cuci tangan.

Hasil penelitian yang dilakukan Asmayanti et al., (2021) menjelaskan terdapat beberapa kendala yang dialami para orang tua yaitu mendisplinkan anggota keluarga dalam menjalani protokol kesehatan dan penambahan biaya untuk memperoleh alat kebersihan pribadi selama masa pandemi Covid-19, adapun upaya yang dapat dilakukan dalam mengatasi problematika tersebut adalah orang tua sebagai pembimbing, pendidik, penjaga, pengembang dan pengawas. Secara spesifik menunjukkan bahwa peran orang tua dalam mencegah covid-19 adalah dengan menjaga dan memastikan seluruh anggota keluarga untuk menerapkan pola hidup bersih dan sehat di masa pandemic Covid-19 (Asmayanti et al., 2021).

Kepala keluarga harus bisa membiasakan keluarganya untuk melakukan penerapan protokol kesehatan seperti kampanye 3M, yaitu; pertama memakai masker dengan benar, demi melindungi anggota keluarga yang memiliki risiko tertular tinggi.Kedua ketika ada keluarga terpapar. Ketiga saat beraktifitas di luar rumah dan Keempat tidak memberikan stigma negatif kepada pasien COVID(Kemenkes, 2020)

Protokol masuk rumah, yaitu; pada saat sampai rumah jangan sentuh apapun, buka sepatu sebelum masuk rumah, buka pakaian dan segera masukan kedalam keranjang cucian, segera mandi, kaluar gak bisa mandi, pastikan cuci semua area kulit yang terkena paparan udara luar, bersihkan handphone atau kacamata dengan desinfektan, bersihkan permukaan atau benda yang dibawa dari luar (Kemenkes RI, 2020).

Hasil penelitian Sagala (2020), menjelaskan bahwa Peran kepala keluarga dalam mencegah Covid-19 setidaknya mencakup empat hal: Pertama, menanamkan pola pikir yang benar tentang penyakit Covid19 dengan memberikan informasi yang tepat dan selengkap-lengkapnya tentang penyakit ini. Kedua, menanamkan sikap yang benar dalam menghadapi penyakit Covid 19 yang memang tidak bisa diremehkan dampaknya bagi keluarga, masyarakat, bangsa dan negara.Ketiga, mengajarkan perilaku yang benar untuk mencegah terjangkitnya anggota keluarga terhadap penyakit Covid 19.Dan keempat, mengajak pada seluruh anggota keluarga untuk menjalankan 8 fungsi keluarga secara bersungguh-sungguh agar penyakit Korona lebih cepat dapat diatasi.

Hasil penelitian yang sejalan dengan penelitian dilakukan Wulandari (2021) menunjukkan hasil analisis data menggambarkan bahwa sikap pencegahan pada kategori kurang memiliki presentase yang cukup besar yaitu 46,6\%. Artinya responden kurang dapat menyikapi dengan tepat dalam hal pencegahan penularan Covid-19. Hal perlu mendapatkan perhatian yang menunjukkan adanya faktor-faktor lain diluar penelitan(Wulandari, 2021).

$\mathrm{Hal}$ ini juga sejalan dengan penelitian Julvainda Eka, dkk (2021) yang menyatakan bahwa edukasi berperan penting dalam pencegahan penyebaran Covid-19. Ada pengaruh pemberian edukasi penerapan protokol kesehatan sebagai upaya pencegahan penyebaran Covid-19 pada penderita komorbid di wilayah kerja puskesmas kota Semarang(Priya Utama, 2021).

Penyuluhan terkait Covid-19 perlu dilakukan pada masyarakat mengenai pencegahan, tanda gejala, perkembangan penyakit, penularan, dan pemeriksaan dini jika ada gejala atau riwayat perjalanan ke luar kota. Penelitian yang dilakukan pada 1096 orang pengguna internet ditemukan bahwa mayoritas mempunyai sikap positif terhadap Covid-19 dan dikatakan pengetahuan berpengaruh pada sikap dan tindakan seseorang dalam upaya pencegahan Covid-19(Syakurah \& Moudy, 2020).

Peranan kepala keluarga pada masa pandemic Covid-19 ini merupakan salah satu kunci pencegahan Covid-19.Karena kepala keluarga memiliki peranan sebagai pendidik dan mengatur aktifitas rumah tangga. Selain itu kepala keluarga juga memiliki peran yang dijalankan terkait merawat anggota keluarga jika ada yang sakit (Friedman, 2015). 


\section{KESIMPULAN}

Peran kepala keluarga terhadap penerapan protokol kesehatan di desa rawa, yaitu sebanyak 39,6\% peran kepala keluarga pada katagori kurang tidak menerapkan protokol kesehatan dan hasil penelitian ini menunjukkan sebanyak 69,8\%kepala keluarga tidak menerapkan protokol kesehatan, hal ini disebabkan oleh persepsi masyarakat yang menganggap penerapan protokol kesehatan tidak begitu penting. Ada hubungan Peran Kepala Keluarga Terhadap Penerapan Protokol Kesehatan Di Desa Rawa Kecamatan Tanah Luas Kabupaten Aceh Utara ( $p$ value $=0,000$; $\alpha=0,05$ ).

Diharapkanuntuk optimalisasi sosialisasi dan edukasi tentang protokol Covid-19 dan peran kepala keluarga dalam masyarakat dengan melibatkan tokoh adat, alim ulama dan tokoh masyarakat, mengoptimalkan gerakan sosialisasi dan penyebarluasan informasi penanganan Covid-19.

\section{REFERENSI}

Asmayanti, Syarif, A., \& Laelasari, E. (2021). Peran Orangtua Pada Keluarga Dalam Mencegah Covid 19. Eduinovasi, 1(1).

Badan Pusat Statistik. (2020). Kuesioner Survei Perilaku Masyarakat di Masa Pandemi. Bps Ri.

Friedman. (2015). Buku Ajar Keperawatan Keluarga Riset, Teori dan Praktik. In Majalah Kedokteran Andalas (Vol. 37, Issue 1).

Hodijah, S., \& Wicaksana, E. J. (2020). Mempersiapkan Masyarakat Dalam Pelaksanaan Protokol. Prosiding Seminar Nasional Interdisiplin Pascasarjana Universitas Jambi 2020.
Kemenkes RI. (2020). Pencegahan Coronavirus Disease 2019. 2020

https://www.kemkes.go.id/article/view/2003170000 1/Dokumen-Resmi-dan-Protokol-PenangananCOVID-19.html

Media, Y. M. (2020). Pengetahuan, Persepsi, dan Sikap Masyarakat Sumatera Barat Terhadap COVID-19. Inovasi, 17(2).

https://doi.org/10.33626/inovasi.v17i2.272

Perhimpunan Dokter Paru Indonesia (PDPI). (2020). Pneunomia COVID-19. In Perhimpunan Dokter Paru Indonesia.

Priya Utama, J. E. (2021). Edukasi Penerapan Protokol Kesehatan Sebagai Upaya Pencegahan Penyebaran Covid-19 Pada Penderita Komorbid. Jurnal IImiah Kesehatan Media Husada, 10(1). https://doi.org/10.33475/jikmh.v10i1.246

Sagala, H. G. (2020). Peran keluarga dan pasien dalam meningkatkan keselamatan dan pencegahan Covid 19. Journal Kesehatan, 4(2).

Soekidjo Notoatmodjo, s. k. m. m. com. . (2018). Metodologi penelitian kesehatan. In RINEKA CIPTA, jAKARTA.

Syakurah, R. A., \& Moudy, J. (2020). Pengetahuan terkait Usaha Pencegahan Coronavirus Disease (COVID-19) di Indonesia. HIGEIA (Journal of Public Health Research and Development), 4(3), 333-346.

https://journal.unnes.ac.id/sju/index.php/higeia/arti cle/view/37844

Wulandari, S. (2021). Hubungan Pengetahuan Dan Sikap Dengan Perilaku Pencegahan Covid-19 Pada Penderita Tuberkulosis Di Rumah Sakit Paru Jember. Journal of Chemical Information and Modeling, 53(9). 